\title{
Paideusis
}

\section{Philosophy of Lifelong Education (Kenneth Wain)}

\section{Mark Selman}

Volume 2, Number 1, 1988

URI: https://id.erudit.org/iderudit/1073421ar

DOI: https://doi.org/10.7202/1073421ar

See table of contents

Publisher(s)

Canadian Philosophy of Education Society

ISSN

0838-4517 (print)

1916-0348 (digital)

Explore this journal

Cite this review

Selman, M. (1988). Review of [Philosophy of Lifelong Education (Kenneth

Wain)]. Paideusis, 2(1), 32-35. https://doi.org/10.7202/1073421ar

(C) Mark Selman, 1988

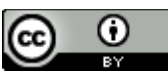

This document is protected by copyright law. Use of the services of Erudit (including reproduction) is subject to its terms and conditions, which can be viewed online.

https://apropos.erudit.org/en/users/policy-on-use/ 


\section{Philosophy of Lifelong Education, by Kenneth Wain. Series in International Perspectives on Adult and Continuing Education. (London: Croon Helm, 1987).}

Kenneth Wain's I'hilosophy of Lifelong Education is an attempt to identify a philosophical position which is consistent with the writings of the lifelong education movement. Wain takes the position of that movement to be defined by UNESCO's Faure report (1972), various commentaries and synopses of the report, and the writings of Ettore Gelpi. His conclusion is that Dewey's philosophy is not only consistent with the essential elements of the lifelong education movement, but that it can be used to transform lifelong education from a loosely connected movement into a coherent 'programme.' The scare quotes are 10 indicate that 'programme' is to be understood in a special sense, that is, as it is employed in Lakatos's theory of methodological falsification.

The conclusion that Dewey's philosophy could be used to inform the work of the lifelong education movement seems sensible enough. Those sections of Wain's book which interpret Dewey and explicate the connections between his work and the fundamental tenets of the lifelong education movement are largely unobjectionable. The same cannot be said for most of the rest of the book in which the work of a wide range of philosophers from Aristotle to Wittgenstein and Peters to Sartre, is distorted and misrepresented. Wain raises many definitional and philosophical issues with which he is unable to deal adequately. A bewildering number of philosophical and theoretical positions are raised for consideration and are summarily divided into the good and the bad. Appearing on the 'good' side are falsificationism, relativism (but not inconsistent forms of relativism), hermeneutics, coherence theories of truth, pragmatism, humanism, and the indistinguishability of ideology from either philosophy or science. Existentialism falls into a grey area and everything else is dismissed as being wrong, if not morally reprehensible.

While little purpose may be served by a comprehensive cataloguing of the ways in which Wain misrepresents the work of various philosophers, a few examples are so extreme as to demand comment. The first and foremost of Wain's targets of criticism are analytic philosophers of education. The extent of his misreading of their work is displayed from the opening pages in which he claims that "the horizons of analytic philosophy had been set by the early Wittgenstein" (p. 2). He goes on to suggest that analytic philosophers are guilty of "scientism," "essentialism," "a kind of atomism," and ignoring questions of context and value. Given that he quotes extensively from R.S. Peters' Ethics and Education, this can only be considered as irresponsible. The first footnote in Peters' 
book is to Wittgenstein's posthumously published Philosophical Investigations. In the opening pages, Peters makes explicit reference to the fact that 'education' is a "family resemblance concept" and Wain quotes his characterization of education as "initiation into a "form of life'." The recognition of family resemblance concepts is a rejection of a certain kind of "essentialism." Both family resemblance concepts and 'forms of life' play an important part in Wittgenstein's later writings, writings which Wain recognizes as being consistent with his own hermeneutic and pragmatic approach. In fact, the central strategies of analytic philosophy (asking how, and for what purpose, a word is used in ordinary language) are derived from Wittgenstein's later writings.

While one might want to argue that Peters misinterprets the later Wittgenstein, that he and other analytic philosophers have seized upon Wittgenstein's methods without grasping his denial of the need for some set of rules which "lie behind" and "explain" ordinary language, to accuse them of ignoring questions of context and value is simply wrong. Wain is, however, too intent on lumping all the evils of essentialism, atomism, and scientism, into one convenient package to attend to such subtleties. So, while Wain may have legitimate complaints about some arguments by some analytic philosophers, his misrepresentation of the field in general is so extreme that his interpretation and criticism of individual arguments can hardly be taken seriously.

Sartre does not fare much better than Wittgenstein and the analytic philosophers. While Wain offers a generally sympathetic treatment of Sartre and other existentialists, he finds their philosophy to be incompatible with the tenets of the lifelong education movement. He suggests that existentialism is radically subjectivist and therefore would lead to rejection of the kinds of educational institutions which lifelong educators believe are required. But, the kind of "alone-ness" which Sartre believed to be part of the human condition has little to do with the existence of particular social institutions. Though Sartre had a rather stormy relationship with political institutions including the Communist Party, his lifelong commitment to social and political action is beyond question. Yet, Wain suggests that the commitment to "social and political action" is what renders the lifelong education movement incompatible with existential philosophy (p. 127). Wain attributes to existentialists a "subjectivist educational philosophy" (p. 129) but there is evidence that Sartre believed in the need for structure and guidance in education. If one considers the pathetic figure of the Auto-didart (or Self-taught Man) in Sartre's Nausea, ploughing uselessly through the books in the library (in alphabetical order), one gets some idea of Sartre's reservations about the very theory of education which Wain assumes existentialists must support. 
Wain's problems with Lakatos are somewhat more complex and difficult to describe briefly, but are important because of their central role in his account. Wain attempts to assimilate Lakatos's theory of methodological falsificationism with the generally pragmatic, hermeneutic trend represented (according to Rorty, and cited by Wain, p. 9) by John Dewey, Heidegger, the later Wittgenstein, Quine, Sellars, and Putnam. Lakatos was, however, vehemently opposed to pragmatism in general, and Wittgenstein's later philosophy in particular. These sentiments are expressed in strong language in his well-known review of Toulmin's Human Vinderstanding. For Lakatos, knowledge and standards of science are objective (specifically, they are objects of Popper's third world) and there are truths about reality independent of human understanding. He rejected as "elitist," philosophies of science which place an emphasis on interpretation.

It is, therefore, difficult to know how Lakatos's methodology is to be assimilated into a pragmatic, hermeneutic philosophy with its reliance on interpretive strategies and historically determined practices as a ground for claims about knowledge. Wain compounds the difficulties by suggesting that the theoretic core of the lifelong education "programme" would not be empirical but ideological. But Lakatos himself expressed great antipathy to the notion of ideological commitment to any claims in any part of a research programme (see Lakatos's "Methodology of scientific research programs," in 1. Lakatos and A. Mugrave (eds.) Criticism and the Growth of Knowledge, Cambridge: University Press, 1977, p. 92.). Since Wain also tells us that the distinction between ideology and science is "fictitious" ( $p$. 24), it all seems quite confusing. We certainly lack any clear idea of how Lakatos's hypothetico-deductive model is to be applied. For Lakatos's methodology to make sense, there must be hypotheses which are falsifiable under specifiable conditions. The method is designed precisely to put hypotheses at risk. But, given the importance of contextual factors to educational situations (recognized by Wain and almost everyone else), and the difficulty of specifying cultural, historical, economic, political, and social conditions, the whole notion of falsifiability seems out of place. I am not trying to deny that some model of conceptual change analogous to Lakatos's might be useful in understanding the evolution of educational ideas. 1 am suggesting that any model inspired by Lakatos's ideas would need to be altered substantially if it was to be incorporated into the set of ideas to which Wain is committed. But Wain does not appear to recognize that there is a problem here and, consequently, does not make any suggestions about how it could be resolved. As a result, the idea which forms the guiding purpose of the book, that of a 'programme' of lifelong education, ought to be understood more as a metaphor than as a methodology for systematically criticizing and evaluating sets of educational ideas. 
Wain's tendency to understand the American pragmatists, especially Rorty and Dewey, as denying any distinctions between judgments of fact and value (p. 182) or between science and morality ( $p$. 9) also contributes to a fundamental confusion at the heart of his project. It. leads him to suggest that there is no difference between "science and ideology," for instance, as if it were a bil of a priori knowledge. $\Lambda$ more perspicuous rendering might be that all scientific inquiry takes place within some worldview, or ideology. Similar care with other distinctions might have led Wain to a more constructive synthesis of his varied sources, instead of the rather arbitrary set of interpretations he has offered.

Mark Selman
University of
British Columbia 